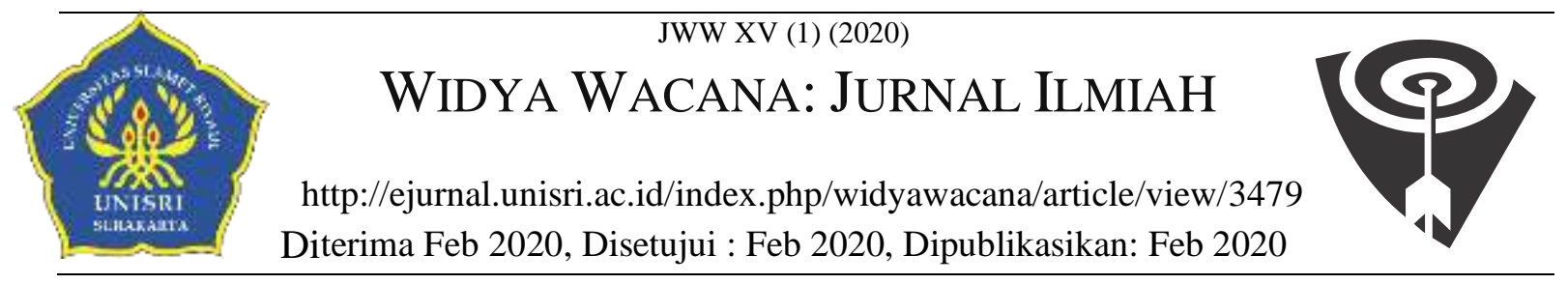

\title{
EFEKTIVITAS PENYULUHAN KOMUNIKASI TERAPEUTIK PRA MENIKAH TERHADAP KESIAPAN DIRI MENUJU PERNIKAHAN
}

\author{
Nurul Lathiffah \\ Magister Psikologi Sains Universitas Mercu Buana Yogyakarta \\ Email: el_thiffa@yahoo.co.id
}

\begin{abstract}
ABSTRAK
Penelitian ini bertujuan untuk mengetahui pengaruh penyuluhan komunikasi terapeutik pra menikah terhadap kesiapan diri menuju perikahan pada calon pengantin muslim. Subjek penelitian ini adalah calon pengantin muslim yang memiliki orientasi pernikahan dengan batasan usia 18 tahun hingga menjelang pernikahan sebanyak 24 subjek. Teknik pengumpulan data dilakukan dengan metode rating yang dijumlahkan (Method of Summated Ratings) dari Likers. Skala yang digunakan satu macam yaitu skala kesiapan pernikahan yang disusun oleh peneliti berdasarkan aspek-aspek kesiapan pernikahan Berger (2005). Teknik analisis data yang digunakan adalah paired sampel $t$ test yang membandingkan hasil pre test dan post test pada kelompok eksperimen dan kelompok kontrol. Hasil penelitian menunjukkan bahwa hipotesis yang menyatakan ada hubungan pengaruh penyuluhan komunikasi terapeutik pra pernikahan pada kesiapan diri menuju pernikahan terbukti. Hal ini dapat diketahui dari hasil uji analisis hipotesis yang menyatakan bahwa $\mathrm{p}=0,007$ yang artinya $\mathrm{p}<0,05$ sehingga terbukti signifikan pada kelomopok yang diberikan penyuluhan. Sedangkan pada kelompok kontrol, tidak ditemukan kesiapan pernikahan yang menigkat secara signifikan terbukti dari uji paired sample $\mathrm{t}$ test yang menyatakan nilai $\mathrm{p}=0,474$ sehingga $\mathrm{p}<0,05$ sehingga tidak memiliki peningkatan kesiapan pernikahan yang signifikan. Hal ini berarti penyuluhan komunikasi terapeutik pra pernikahan dapat meningkatkan kesiapan diri pada individu pra menikah, khususnya dalam aspek kematangan psikologis, yakni mengasah keterampilan komunikasi dan penerimaan positif.
\end{abstract}

Kata Kunci: Penyuluhan, Komunikasi, Terapeutik, Pernikahan

\begin{abstract}
This study discusses the importance of pre-marital therapeutic communication for self-readiness for marriage to Muslim brides. The subjects of this study were Muslim brides who have marriage consent with an age limit of 18 years for marriage approval of 24 subjects. The technique of collecting data is done by the summed rating method (Summated Ratings Method) from Likers. The scale used is a kind of marriage readiness scale compiled by researchers based on aspects of Berger's marriage readiness (2005). The data analysis technique used was paired t-test samples comparing the results of pre-test and post-test in the experimental group and the control group. The results of the study prove the hypothesis which states there is a connection with the communication of therapeutic communication before marriage on the readiness of self towards marriage is proven. This can be seen from the results of the hypothesis analysis which states $p=0.007$ which means that $p<0.05$ is proven significant in the group given the discussion. Whereas in the control group, no marriage readiness was found to be significantly proven from a paired sample test, the t test proved the value of $p=0.474$ so that $p<0.05$ so that it did not have a significant increase in marriage readiness. This means increasing pre-marital therapeutic communication can increase self-readiness in pre-marital individuals, specifically in the aspect of psychological maturity, namely honing communication skills and positive acceptance.
\end{abstract}

Keywords: Counseling, Communication, Therapeutic, Marriage 


\section{PENDAHULUAN}

Masa transisi dari masa pra pernikahan menuju masa pernikahan tentu memiliki kompleksitas dan dinamika yang berbeda. Masa transisi, hampir selalu dihadapi oleh setiap individu dalam setiap tugas dan fase perkembangan. Masa transisi adalah masa di mana seeorang membutuhkan persiapan-persiapan tertentu, yang harus dilewati, biasanya dicirikan dengan keadaan yang tidak stabil. Sayangnya, posisi calon pasangan pra menikah yang dianggap 'matang' seringkali membuat masyarakat secara kolektif dan massal 'mengabaikan' kebutuhan calon pasangan pra pernikahan.

Senada dengan paradigma di atas, papalia dan Olds (1986) mengemukakan bahwa masa dewasa awal adalah salah satu tahapan perkembangan manusia yang memiliki masa terpanjang sepanjang rentang kehidupan seseorang. Pada masa dewasa awal individu dianggap telah siap menghadapi suatu perkawinan, seperti yang dikemukakan oleh Havigurst bahwa lima dari tugas perkembangan dewasa awal merupakan kegiatan-kegiatan pokok yang bersangkutan dengan kehidupan berkeluarga

Desmita (2008) mengemukakan bahwa ketika akan melangsungkan pernikahan, hampir semua orang mengharapkan hubungan yang langgeng dan penuh pengertian. Akan tetapi, karena perkawinan menuntut adanya penyesuaian diri terhadap peran dan tanggung jawab baru, harapan itu sering kandas dan tidak menjadi kenyataan. Hal ini disebabkan karena penyesuaian diri bukan suatu hal yang mudah bagi pasangan baru.

Pernikahan bukanlah hal yang mudah, di dalamnya terdapat banyak konsekuensi yang harus dihadapi sebagai suatu bentuk tahap kehidupan baru individu dewasa dan pergantian status dari lajang menjadi seorang istri yang menuntut adanya penyesuaian diri terus-menerus sepanjang perkawinan (Hurlock, 1993).

Penyesuaian diri dalam kehidupan pernikahan tentu menjadi suatu hal yang sangat berbeda jika dibandingkan dengan penyesuaian dalam bentuk interaksi sosial dalam masyarakat. Artinya, dalam pernikahan ada komponen keluarga dan famili yang dengan mereka pengantin baru memiliki ikatan kekeluargaan yang baru, hubungan emosional yang baru, dengan latar budaya kebiasaan dan bahkan budaya yang tidak selalu sama. Menggabungkan ekspektasi pasangan dengan diri, kedua orang tua dan mertu memerlukan kematangan psikologis dan keterampilan komunikasi yang mampu menumbuhkan pertumbuhan psikologis seseorang pada arah yang lebih optimal. Hal ini sesuai dengan pendapat Landis bahwa individu yang siap secara psikologis untuk menikah akan bersikap flexibel dan adaptif dalam menjalin hubungan dengan orang lain, memandang pernikahan sebagai sebuah fase dalam kehidupan yang akan dapat mendatangkan berbagai persoalan baru yang tentunya memerlukan tanggung jawab lebih besar (Landis, 1963).

Desmita (2009) memaparkan bahwa selama masa dewasa, dunia sosial dan personal dari individu menjadi luas dan kompleks dibandingkan dengan masa-masa sebelumnya. Pada masa dewasa ini individu memasuki peran kehidupan yang lebih luas. Keintiman termasuk dalam komponen yang ada dalam periode pernikahan dan karir. Lebih lanjut, Erikson (dalam Desmita, 2009) menyatakan bahwa pembentukan hubungan intim merupakan tantangan utama yang dihadapi oleh orang-orang yang memasuki masa dewasa. Pada masa dewasa awal ini, orang-orang telah siap dan ingin menyatukan identitasnya dengan orang lain. Mereka mendambakan hubungan-hubungan yang intim akrab, dilandasi rasa persaudaraan, serta siap mengembangkan daya-daya yang dibutuhkan untuk memenuhi komitmenkomitmen ini.

Papalia, Sally Wendkos Old \& Ruth Duskin Feldman (2008) mengemukakan biasanya masa dewasa awal merupakan waktu perubahan dramatis dalam relasi personal ketika orang-orang mmebentuk, menegosiasikan kembali, atau mempererat ikatan yang berdasarkan pertemanan, cinta, dan seksualitas. Erikson memandang hubungan yang intim sebagai kebutuhan yang sangat bermakna pada masa dewasa awal. Baumeister \& Leary (dalam Papalia, Sally 
Wendkos Old \& Ruth Duskin Feldman, 2008) menjelaskan bahwa keintiman juga mencakup rasa memiliki. Kebutuhan untuk membentuk hubungan yang kuat, stabil, dekat, saling peduli, merupakan motivator terkuat perilaku manusia.

Sebuah studi yang dilakukan Traupmann dan Hatfield pada tahun 1981 (dalam Desmita, 2009) menyatakan bahwa hubungan intim mempunyai pengaruh yang besar dalam perkembangan fisik dan psikologis seseorang. Orang-orang yang mempunyai tempat untuk berbagi ide, perasaan, dan masalah, merasa lebih bahagia dan lebih sehat dibandingkan dengan mereka yang tidak memiliki tempat untuk berbagi. Keintiman dengan demikian merupakan suatu kebutuhan yang sangat bermakna bagi individu pada masa dewasa.

Hurlock (2000) mendefinisikan bahwa masa dewasa dini merupakan periode penyesuaian diri terhadap pola-pola kehidupan baru dan harapan-harapan sosial baru. Orang dewasa muda diharapkan memainkan peran baru seperti peran suami atau istri, orang tua, pencari nafkah, mengembangkan sikap-sikap baru, keinginan dan nilai baru sesuai dengan tugas-tugas baru. Penyesuaian diri ini menjadikan periode ini suatu periode khusus dan sulit dari rentang hidup seseorang. Hurlock (2000) juga mengemukakan bahwa ada tiga alasan yang menyebabkan individu pada masa dewasa awal memiliki kesulitan dalam hal penyesuaian diri. Pertama, sedikit sekali orang muda yang mempunyai persiapan untuk menghadapi jenis-jenis masalah yang perlu diatasi oleh orang dewasa. Kedua, mencoba menguasai berbagai keterampilan baru biasanya akan menyebabkan kurang berhasil. Alasan yang ketiga adalah individu pada masa dewasa awal tidak lagi memperoleh bantuan menghadapi dan memecahkan masalah-masalah mereka seperti pada masa sebelum dewasa.

Sementara itu, ada konflik-konflik yang timbul antara pria dan wanita yang mulai berniat melaksanakan tugas perkembangan pada masa dewasa awal. Konflik-konflik yang timbul mememrlukan penyesuaian diri sebagai faktor pendukung yang akan mengurangi ketegangan emosional yang dialami pada masa dewasa awal. Gray (1993) mengemukakan bahwa banyak pria tidak sukses dalam melakukan pergantian peran ketika mereka tumbuh dewasa. Bagi mereka, memiliki cinta, menikahm dan memiliki keluarga adalah sam sulitnya dengan terbang pada pesawat jet besar tanpa adanya pelatihan. Tanpa sebuah pelatihan yang bagus dalam hubungan khusus, sangat mudah dimengerti alasan mengapa banyak pria dan wanita gagal dalam menjalin sebuah hubungan.

Selanjutnya, Gray (1993) juga mengungkapkan bahwa tanpa kesadaran bahwa laki-laki dan perempuan berbeda, lakilaki dan perempuan akan saling terpisah satu dengan yang lainnya. Seseorang biasa marah dengan lawan jenisnya karena lupa kebenaran itu. Seseorang mengharapkan lawan jenis atau pasangannya seperti dirinya sendiri. Seseorang mengharapkan untuk memiliki harapan dan perasaan yang sama. Lebih lanjut, Gray (1993) mengemukakan bahwa komunikasi adalah sangat penting untuk membagi perasaan, dan hal ini lebih penting daripada mencapai tujuan dan sukses.

Santrock (1995) mendefinisikan pasangan baru sebagai fase kedua dari siklus kehidupan keluarga di mana dua individu dari dua keluarga yang berbeda bersatu untuk membentuk satu sistem keluarga yang baru. Pada periode pelepasan usai menikah, individu merumuskan tujuan hidupnya untuk membangun identitas dan memerlukan pola komunikasi dengan orang lain dalam kualitas hubungan yang positif, dewasa, matang, dan sehat. Komunikasi terapeutik, bermanfaat dalam memudahkan memahami perasaan orang lain, menumbuhkan sikap sabar, pengertian, dan merupakan bentuk komunikasi yang menyembuhkan karena meminjam konsep konseling Rogers, yakni unconditional positive regards.

Sejauh ini, penyuluhan pada pasangan pra menikah dilakukan secara formalitas dengan 'mengabaikan' kebutuhan psikologis calon pasangan. Hal ini kemudian memanjang menjadi persiapan yang kurang dan persiapan adaptasi sosial yang rendah, baik kepada pasangan atau pada keluarga baru. Kompleksitas permasalahan yang dihadapi pada saat awal pernikahan pun tidak 
bisa dikatakan sederhana. Karena itulah, penyuluhan mengenai komunikasi terapeutik ini diperlukan. Komunikasi terapeutik dalam pemahaman psikologis adalah komunikasi yang menyembuhkan, penuh pengertian, empati, dewasa, memahami, dan sehat.

Penyuluhan ini diharapkan dapat menjadi sebuah 'investasi" dalam rangka melahirkan anak anak yang sejahtera, terpenuhi kebutuhan rasa aman dan kasih sayang dalam keluarga, serta meningkatkan kualiatas budaya verbal masyarakat Indonesia secara luas, menjadi memiliki kualiatas verbal dan bahasa lisan yang terapeutik (menyembuhkan). Dewasa ini semakin tampak fenomena 'orang sakit mental' akan mampu sembuh dengan pola komunikasi terapeutik. Berawal dari hal itu, diharapkan penyuluhan komunikasi terapeutik ini akan memberi kontribusi dalam jangka panjang, dan membawa kemanfaaatan yang berkesinambungan.

Dasar mengenai komunikasi terapeutik ini berakar dari konsep yang sifatnya sangat psikologis. Pola komunikasi ini pada awalnya digunakan oleh psikolog dan terapis untuk 'menyembuhkan' dan 'memotivasi klien'. Prihatono (1996) mengemukakan bahwa pola komunikasi yang hangat dan humanis semacam sangat cocok diterapkan dalam komunikasi kepada pasangan hidup dan keluarga, dalam rangka mengupayakan pola komunikasi yang sehat, pengertian, dan terbuka.

Beberapa penelitian mengemukakan hasil bahwa pernikahan membuat kehidupan seseorang menjadi jauh lebih bahagia. Horwitz et al (dalam Papalia, Sally Wendkos Old \& Tuth Duskin Feldman, 2008) mengemukakan bahwa pernikahan memiliki kaitan yang berbeda antara suami dan istri dalam kesehatan fisik. Dalam sebuah studi tujuh tahun terhadap 1.201 orang dewasa muda berkulit putih, pria yang menikah berkecenderungan lebih kecil menjadi lebih tertekan dan wanita yang juga menikah berkecenderungan lebih kecil mengembangkan masalah alcohol disbanding mereka yang terus melajang. Hasil penelitian senada juga diungkapkan Ross et al (dalam Papalia, Sally Wendkos Old \& Tuth Duskin
Feldman, 2008) yang mengemukakan bahwa orang yang menikah juga cenderung lebih baik secara finansial, faktor yang diasosiasikan dengan kesehatan fisik dan mental. Lebih lanjut, De Vvavus, et al (dalam Papalia, Sally Wendkos Old \& Tuth Duskin Feldman, 2008) bahwa orang yang menikah khususnya pria cenderung lebih sehat secara fisik dan-dalam beberapa riset-secara psikologis dibandingkan dengan mereka yang tidak pernah menikah, menjanda, berpisah, dan khususnya bercerai.

Nikah dalam bahasa Arab (nakaha), secara etimologis mempunyai dua arti, yaitu arti sebenarnya dan arti kiasan. Menurut arti sebenarnya, nikah adalah menghimpit, menindih, atau berkumpul. Sedangkan menurut arti kiasan adalah setubuh atau mengadakan perjanjian pernikahan. Jika ditinjau dari kepastian hukum dan pemakaian perkataan dalam Al Qur'an dan al hadis, maka nikah dengan arti perikatan lebih tepat dan banyak dipakai daripada nikah dalam arti setubuh (Mukhtar, dalam Muttaqien, 2006).

Sedangkan, kata 'nikah' ditinjau dari segi bahasa berarti mengikat tali perkawinan. Adapun nikah ditinjau dari segi syariat adalah pertalian hubungan akad antara laki-laki dan perempuan dengan maksud agar masingmasing dapat melakukan istimtaa' dan untuk membentuk keluarga yang saleh dan membina masyarakat yang bersih (Al Utsaimin \& Aziz, 1994).

Marshall \& Marshall (dalam Lasswell \&Lasswell, 1987) mengemukakan bahwa kesulitan dari penyesuaian pernikahan adalah kehidupan rumah tangga jauh dari apa yang dibayangkan dan diketahui sebelum pernikahan. Selanjutnya, Lasswell \& Lasswell (1987) mengemukakan bahwa konsep dari penyesuaian diri pada pernikahan membawa implikasi bahwa dua individu yang saling belajar mengakomodasi kebutuhan masing-masing pasangannya, keinginan, dan harapannya. Penyesuaian diri dalam pernikahan mendong menuju derajat yang baik dan nyaman dalam hubungan yang mutual antara memberi dan menerima.

Kesiapan pernikahan adalah suatu hal yang sangat penting dalam membina kehidupan pernikahan. Kesiapan adalah setengah keberhasilan (Fantastik, 2000). 
Kesiapan menikah dengan demikian memainkan peran yang bermakna dalam mewujudkan pernikahan yang berkualitas. Kesiapan pernikahan berdasarkan (Berger) ditandai dengan beberapa indikator kesesuaian dalam aspek kesiapan pernikahan, yakni kesiapan fisik, materi, agama, dan psikologis. Aspek psikologis yang sangat bermakna dalam kesiapan pernikahan, salah satunya adalah komunikasi pada pasangan.

Hipotesis pada penelitian ini adalah, terdapat pengaruh penyuluhan komunikasi terapeutik pada individu pra menikah dalam hal kesiapan pernikahan. Setelah individu pra menikah yang mengikuti penyuluhan komunikasi terapeutik, inidividu pra menikah memiliki tingkat kesiapan pernikahan yang lebih tinggi daripada sebelum penyuluhan.

\section{METODE}

Berdasarkan landasan teori yang ada serta rumusan hipotesis penelitian maka yang menjadi variabel dalam penelitian ini adalah:

1. Variabel Bebas

Penyuluhan a. Komunikasi Terapeutik Pra Pernikahan

2. Variabel Terikat : Kesiapan Pernikahan

Penelitian ini adalah penelitian eksperimen murni (true eksperiment). Desain penelitian yang digunakan dalam penelitian ini adalah two group pre-test posttest design, yaitu desain eksperimen yang menggunakan $b$. satu kelompok eksperimen dan satuc. kelompok kontrol serta melakukan pengukuran sebelum dan sesudah pemberian perlakuan pada subjek. Perbedaan kedua hasil pengukuran tersebut dianggap sebagai efek dari perlakuan yang diberikan (Latipun, 2006). Rancangan penelitian eksperimen tersebut akan dijelaskan dengan tabel berikut ini:

Tabel Rancangan Eksperimen

\begin{tabular}{|l|l|l|l|}
\hline Kelompok & $\begin{array}{l}\text { Pre- } \\
\text { test }\end{array}$ & Perlakuan & $\begin{array}{l}\text { Post- } \\
\text { test }\end{array}$ \\
\hline Eksperimen & SK 1 & $\begin{array}{l}\text { Penyuluhan } \\
\text { Komunikasi } \\
\text { Terapeutik } \\
\text { Pra } \\
\text { Pernikahan }\end{array}$ & SK 2 \\
\hline Kontrol & SK 1 & $\begin{array}{l}\text { Tanpa } \\
\text { Perlakuan }\end{array}$ & SK 2 \\
\hline
\end{tabular}

Keterangan:

SK 1 : skor skala kesiapan pernikahan sebelum perlakuan

SK 2 : skor skala kesiapan pernikahan setelah perlakuan

Prosedur penelitian eksperimen ini terbagi ke dalam (1) persiapan penelitian, yang meliputi pra eliminary research, dengan cara depth interview kepada individu pra menikah, (2) penyusunan alat ukur, (3) penyusunan modul penyuluhan komunikasi terapeutik, (4) Training for Trainer (TFT), dan (5) pelaksanan eksperimen. Persiapan penelitian meliputi persiapan perizinan, wawancara mendalam dan observasi kancah wilayah penelitian, studi awal untuk mendapatkan informasi mengenai subjek penelitian, dan sosialisasi mengenai penyuluhan yang akan dilakukan. Karakteristik populasi pada penelitian ini adalah:

Individu memiliki persepsi positif terhadap pernikahan dan memiliki orientasi menikah. Hal ini senada dengan Latipun (2006) yang mengemukakan bahwa homogenitas populasi sangat berguna bagi kemudahan dalam pengambilan sampel dan intervensi yang hendak diberikan.

Individu muslim pra nikah.

Bersedia menyepakati untuk dapat menjadi peserta aktif dalam penyuluhan. Hal ini dilakukan agar peserta bersikap antusias dalam penyuluhan dan mengurangi kemungkinan adanya subjek yang menggugurkan diri di tengah proses penelitian.

Teknik pengumpulan data yang digunakan pada penelitian ini adalah dengan menggunakan skala. Ada dua kelompok subjek yang akan diteliti, yakni kelompok subjek eksperimen dan kelompok subjek kontrol. Alat ukur yang digunakan dalam penelitian ini adalah skala kesiapan pernikahan berdasarkan aspek-aspek dari Badger (2005):

a. Kematangan fisik, (bagi wanita setelah usia 18-20 tahun), bagi pria usia 25 tahun.

b. Kesiapan materi (bagi suami)

c. Kematangan psikologis (mampu mengendalikan diri, tidak kekanak- 
kanakan, tidak mudah tersinggung, mau menerima kehadiran orang lain, mempunyai sikap toleran, mau menghargai orang lain, memahami karakteristik dirinya atau calon suaminya).

d. Kematangan agama (memiliki pemahaman dan keterampilan dalam masalah agama, sudah menjalankan ibadah, dan dapat mengajarkan agama kepada anak).

Definisi operasional dari penyuluhan komunikasi terapeutik pada penelitian ini

Tabel 1

Alur Materi Penyuluhan Komunikasi Terapeutik

\begin{tabular}{|l|l|l|}
\hline No & Materi & $\begin{array}{l}\text { Tujuan/ Indikator } \\
\text { Pencapaian }\end{array}$ \\
\hline 1 & $\begin{array}{l}\text { Komunikasi } \\
\text { yang Efektif } \\
\text { dalam } \\
\text { Pernikahan }\end{array}$ & $\begin{array}{l}\text { Peserta mampu } \\
\text { memahami dasar-dasar } \\
\text { mewujudkan } \\
\text { komunikasi yang efektif } \\
\text { dalam pernikahan. }\end{array}$ \\
\hline 2 & $\begin{array}{l}\text { Memahami } \\
\text { Gaya } \\
\text { Bahasa Laki } \\
\text { Vs } \\
\text { Perempuan }\end{array}$ & $\begin{array}{l}\text { Peserta mampu } \\
\text { memahami perbedaan } \\
\text { gaya bahasa laki-laki } \\
\text { dan gaya bahasa } \\
\text { perempuan sehingga } \\
\text { membuat peserta } \\
\text { terampil memahami } \\
\text { perasaan yang } \\
\text { cenderung dirasakan } \\
\text { pasangannya nanti. }\end{array}$ \\
\hline 3 & $\begin{array}{l}\text { Mendengar } \\
\text { kan Aktif: } \\
\text { Solusi } \text { Miss } \\
\text { Communica } \\
\text { tion }\end{array}$ & $\begin{array}{l}\text { Peserta mampu } \\
\text { memiliki dasar } \\
\text { keterampilan } \\
\text { mendengarkan aktif dan } \\
\text { mampu } \\
\text { mempraktikannya } \\
\text { selama 5 menit. }\end{array}$ \\
\hline 4 & $\begin{array}{l}\text { Komunikasi } \\
\text { yang } \\
\text { Menyembu }\end{array}$ & $\begin{array}{l}\text { Peserta mampu } \\
\text { memahami dasar dan } \\
\text { prinsip komunikasi } \\
\text { yang menyembuhkan } \\
\text { luka kecewa dan sakit } \\
\text { hati yang dialami } \\
\text { pasangan atau orang- } \\
\text { orang terdekatnya dan } \\
\text { memiliki bekal } \\
\text { keterampilan untuk }\end{array}$ \\
\hline
\end{tabular}

adalah penyuluhan yang diberikan kepada calon pasangan yang hendak menikah dengan durasi waktu 2 jam dengan menyajikan pemahaman materi yang bersifat kognitif, berdasarkan kurikulum afeksi sehingga penyuluhan komunikasi terapeutik pra pernikahan ini mengandung pembelajaran 'olah rasa'. Adapun beberapa materi yang disajikan berdasarkan analisa kebutuhan materi penyuluhan komunikasi terapeutik adalah sebagai berikut,

\begin{tabular}{|c|c|c|}
\hline & & $\begin{array}{l}\text { mempraktikkan pola } \\
\text { komunikasi terapeutik. }\end{array}$ \\
\hline 5 & $\begin{array}{l}\text { Komunikasi } \\
\text { Terapeutik } \\
\text { Berbasis Al } \\
\text { Qur'an }\end{array}$ & $\begin{array}{l}\text { Peserta mampu } \\
\text { menerapkan akhlak } \\
\text { berbahasa dalam Al } \\
\text { Qur'an pada kehidupan } \\
\text { sehari-hari dan } \\
\text { memberikan } \\
\text { keteladanan positif } \\
\text { terhadap diri dan } \\
\text { lingkungannya. }\end{array}$ \\
\hline 6 & $\begin{array}{l}\text { Keterampila } \\
\mathrm{n} \\
\text { Merefleksik } \\
\text { an Perasaan }\end{array}$ & $\begin{array}{l}\text { Peserta mampu } \\
\text { memiliki bekal } \\
\text { keterampilan } \\
\text { merefleksikan perasaan } \\
\text { yang merupakan } \\
\text { komponen dari } \\
\text { kecerdasan emosi dan } \\
\text { keterampilan } \\
\text { komunikasi yang } \\
\text { menyembuhkan. }\end{array}$ \\
\hline 7 & $\begin{array}{l}\text { Mengelola } \\
\text { Konflik } \\
\text { Menjadi } \\
\text { Perekat } \\
\text { Hubungan }\end{array}$ & $\begin{array}{l}\text { Peserta mampu secara } \\
\text { bijak dan kreatif } \\
\text { mempersepsi konflik } \\
\text { dan hal yang } \\
\text { membuatnya 'sakit' } \\
\text { sebagai suatu hal yang } \\
\text { positif dan penuh } \\
\text { hikmah, serta memiliki } \\
\text { bekal keterampilan } \\
\text { untuk mengelola } \\
\text { konflik yang ia hadapi. }\end{array}$ \\
\hline 8 & $\begin{array}{l}\text { Mengasah } \\
\text { Keterampila } \\
\text { n } \\
\text { Mengapresi } \\
\text { asi }\end{array}$ & $\begin{array}{l}\text { Peserta mampu } \\
\text { menemukan dan } \\
\text { membiasakan diri untuk } \\
\text { mengapresiasi orang } \\
\text { lain dan memberikan } \\
\text { penghargaan tulus } \\
\text { kepada orang lain. }\end{array}$ \\
\hline
\end{tabular}


HASIL

Berdasarkan hasil uji hipotesis pada subjek eksperimen, penyuluhan komunikasi terapeutik memiliki pengaruh yang signifikan dalam meningkatkan kesiapan pernikahan pada individu pada individu pra menikah. Hal ini berdasarkan hasil uji signifikansi yang memiliki nilai $\mathrm{p}=0,007$ sehingga $\mathrm{p}<0,05$ menghasilkan interpretasi bahwa hipotesis yang diajukan terbukti signifikan. Dengan demikian, uji hipotesis pada kelompok eksperimen yang diberi perlakuan berupa penyuluhan komunikasi terapeutik pra menikah menghasilkan kesimpulan bahwa penyuluhan komunikasi terapeutik pra menikah terbukti signifikan meningkatkan kesiapan pernikahan dalam aspek kematangan psikologis.

Sedangkan, berdasarkan hasil Hasil uji hipotesis pada kelompok kontrol menunjukkan bahwa $\mathrm{p}=0,474$. Hal ini menunjukkan bahwa $\mathrm{p}>0,05$ sehingga hasil uji hipotesis tidak signifikan. Dengan demikian, pada subjek yang tidak diberi perlakuan berupa penyuluhan komunikasi terapeutik pra pernikahan tidak menunjukkan adanya peningkatan kesiapan pernikahan secara signifikan. Klasifikasi subjek pada saat pre test pada seluruh subjek adalah sebagai berikut,

Kategorisasi Data Kesiapan Pernikahan Pada saat Pre Test

\begin{tabular}{|c|c|c|}
\hline Skor & Kategori & $\begin{array}{c}\text { Jumlah } \\
\text { Subjek }\end{array}$ \\
\hline $63 \leq \mathrm{x} \leq 84$ & Tinggi & 11 \\
\hline $42 \leq \mathrm{x} \leq 63$ & Sedang & 13 \\
\hline $21 \leq \mathrm{x} \leq 42$ & Kurang & - \\
\hline
\end{tabular}

Berdasarkan hasil analisis telah diketahui bahwa dalam penelitian ini perlakuan yang berupa penyuluhan komunikasi terapeutik mampu meningkatkan kesiapan pernikahan individu dalam aspek kematangan psikologis secara signifikan. Artinya, subjek yang mengikuti penyuluhan memiliki angka kesiapan pernikahan yang meningkat daripada subjek yang tidak mengikuti penyuluhan (subjek kontrol). Hal ini menunjukkan bahwa hipotesis yang diajukan peneliti terbukti.
Diterimanya hipotesis ini menunjukkan bahwa penyuluhan komunikasi terapeutik efektif dalam meningkatkan kesiapan diri calon pengantin dalam mencapai pernikahan. Aspek kematangan psikologis, yang di dalamnya terdapat komponen ketrampilan komunikasi dengan demikian memiliki pengaruh yang signifikan dalam kesiapan pernikahan. Pengetahuan mengenai pola komunikasi laki-laki perempuan dan praktik komunikasi terapeutik secara signifikan mampu meningkatkan kesiapan pernikahan pada calon pengantin muslim.

Hal tersebut bersesuaian dengan pernyataan Gray (1993) bahwa tanpa kesadaran bahwa laki-laki dan perempuan berbeda, laki-laki dan perempuan akan saling terpisah satu dengan yang lainnya. Seseorang biasa marah dengan lawan jenisnya karena lupa kebenaran itu. Seseorang mengharapkan lawan jenis atau pasangannya seperti dirinya sendiri. Seseorang mengharapkan untuk memiliki harapan dan perasaan yang sama. Lebih lanjut, Gray (1993) mengemukakan bahwa komunikasi adalah sangat penting untuk membagi perasaan, dan hal ini lebih penting daripada mencapai tujuan dan sukses. Penyuluhan komunikasi terapeutik dengan durasi 2 jam ini memiliki efektivitas yang bermakna karena calon pengantin dapat mengembangkan skill keterampilan baik berupa akhlak yang baik dan afeksi positif setelah mendapatkan materi yang bersifat kognitif. Praktik mendengar empati, membiasakan diri melakukan apresiasi positif membuat calon pengantin memiliki bekal keterampilan komunikasi yang membuat pasangannya nyaman.

1) Penutup

Berdasarkan hasil uji statistika dan pembahasan dapat disimpulkan bahwa secara empirik, penyuluhan komunikasi terapeutik pra menikah dapat meningkatkan skor kesiapan pernikahan. Hal ini dapat dilihat dari peningkatan skor empirik yang dapat diamati berdasarkan hasil pre test dan post test pada kelompok eksperimen. Hasil analsis statistika juga menunjukkan bahwa penyuluhan komunikasi terapeutik terbukti signifikan untuk meningkatkan kesiapan pernikahan pada individu pra menikah. 
Selanjutnya, berdasarkan hasil penelitian mengenai pengaruh penyuluhan komunikasi terapeutik pra pernikahan peneliti memberikan saran,

a. Kepada calon pengantin untuk membekali diri dengan skill yang memadai dalam upaya komunikasi, membangun empati, dan akhlak yang baik sehingga hal ini dapat menjadi bekal yang sangat bermakna dalam proses pernikahan.

b. Kepada institusi KUA agar semakin intens memberikan penyuluhan komunikasi pra pernikahan yang dapat dengan mudah diakses juga memiliki konten materi yang sesuai dengan kebutuhan individu pra menikah.

c. Kepada masyarakat, hendaknya mendukung tercapainya program penyuluhan pra menikah dengan membangun persepsi positif mengenai penyuluhan pra menikah pada calon pengantin.

Materi komunikasi terapeutik hendaknya menjadi suatu hal yang dapat dengan mudah diakses oleh masyarakat sehingga kemanfaatannya bisa dirasakan secara kolektif dan berkesinambungan.

\section{DAFTAR PUSTAKA}

Adhzim, Faudzil. 2006. Kupinang Engkau dengan Hamdalah. Yogyakarta: Pro U Media

A Fillah, Salim. 2008. Bahagianya Merayakan Cinta. Yogyakarta: Pro U Media

Bagio, Prihatono. 1996. Cara Membina Hubungan Baik dengan Orang Lain. Jakarta: Bumi Aksara

Creswell, John W. 2007. Second Edition Qualitative inquiry and Research Design Choosing Among Five approach. Lincoln:SAGE Publication.

Davidoff, L.L. 1988. Introduction to Psychology. Terj. Mari Juniati. Jakarta: Erlangga.

Desmita. 2009. Psikologi Perkembangan. Bandung: Remaja Rosdakarya.

Desmita. 2008. Psikologi Perkembangan. Bandung: Remaja Rosda Karya.

Hurlock, Elizabeth B. 2000. Psikologi Perkembangan; suatu pendekatan sepanjang rentang kehidupan. Terj. Istiwidayanti. Jakarta: Erlangga.
Mappiare, Andi. 1983. Psikologi Orang Dewasa. Surabaya: Usaha Nasional

Latipun. 2006. Psikologi Konseling. Malang: UMM Press

Lasswell, Marcia, And Lassell, Thomas, 1987. Marriage and The Family. Second Edition. California: Wodsworth Publishing Company.

Schualtz, Duane. 1991. Psikologi Pertumbuhan. Jakarta: Kanisius

Willy, Chandra. 1999. Kekerasan pada Istri dalam Rumah Tangga. Tugas Akhir. Surabaya: Politeknik Negeri Surabaya.

Santrock, John W. 1995. Life Span Development; perkembangan masa hidup. Terj. Ahmad Qusairi. Jakarta: Erlangga.

Santrock, John W. 2005. Adolescence. New York: Higher Education.

Strauss, Anselm dan Juliet Corbin. 2003. Dasar-dasar Penelitian Kualitatif. Yogyakarta : Pustaka Pelajar.

Setianti, Yanti. 2007. Komunikasi Terapeutik Antara Perawat dengan Pasien. Makalah Ilmiah. Jawa Tengah: Universitas Padjajaran.

Moleong, Lexy J. 2008. Metodologi Penelitin Kualitatif. Bandung : Remaja Rosda Karya.

O Hair, et all. 2009. Strategic Communication in Business and the Professions. Terj. Tri Wibowo. Jakarta: Kencana.

Sugiyono. 2006. Metode Penelitian Pendidikan: pendekatan kuantitatif, kualitatif, dan $R \& D$. Bandung: Alfabeta.

Willis, Sofyan S. 2009. Konseling Keluarga (Family Counseling). Bandung: Alfabeta. 